\title{
SOBRE O AUTOR ${ }^{*}$
}

José Luiz Fiorin é Professor Associado do Departamento de Lingüística da Faculdade de Filosofia, Letras e Ciências Humanas da Universidade de São Paulo. Foi membro do Conselho Deliberativo do CNPq (2000 - 2004) e representante da área de Letras e Lingüística na CAPES (1995 - 1999).

Dentre suas publicações, destacam-se a produção das obras

As astúcias da enunciação. As categorias de pessoa, espaço e tempo. São Paulo: Ática, 1996.

Introdução ao Pensamento de Bakhtin. São Paulo: Ática, 2006.

Elementos de Análise do Discurso. São Paulo: Contexto / EDUSP, 2005.

e a organização dos livros

Introdução à Lingüística I: Objetos teóricos. São Paulo: Contexto, 2002

Introdução à Lingüística II: Princípios de análise. São Paulo: Contexto, 2005

Dicionário Gramatical de Verbos do Português Contemporâneo do Brasil. São Paulo: Editora da UNESP, 1990.

* Texto elaborado por Marluza Terezinha da Rosa, aluna do Programa de PósGraduação em Letras - Mestrado em Letras, da Universidade Federal de Santa Maria. 